\title{
Indoor radon levels in workplaces of Adapazarı, north-western Turkey
}

\author{
Enis KAPDAN ${ }^{1}$ and NesRin Altinsoy ${ }^{2, *}$ \\ ${ }^{1}$ Cekmece Nuclear Researches and Training Centre, Altinsehir Yolu, Halkali, Istanbul 34303, Turkey. \\ ${ }^{2}$ Institute of Energy, Istanbul Technical University (ITU), Ayazaga Kampusu, Istanbul 34469, Turkey. \\ *Corresponding author.e-mail: altinsoy@itu.edu.tr
}

The main objective of this study is to assess the health hazards due to radon gas accumulation and to compare the concentrations in different kinds of workplaces, in the city of Adapazarı, one of the most important industrial cities of Turkey. For this purpose, radon activity concentration measurements were carried out in schools, factories, offices and outdoors using CR-39 solid state nuclear track detectors (SSNTD). Results show that the mean radon activity concentrations (RAC) in schools, offices and factories were found to be 66,76 and $27 \mathrm{~Bq} / \mathrm{m}^{3}$, respectively, with an outdoor concentration of $14 \mathrm{~Bq} / \mathrm{m}^{3}$. The average concentrations were found to decrease as follows for different types of industries: automotive $>$ electronic $>$ metal $>$ textile. Because the maximum measured radon concentrations are $151 \mathrm{~Bq} / \mathrm{m}^{3}$ in the schools, $173 \mathrm{~Bq} / \mathrm{m}^{3}$ in the offices and $52 \mathrm{~Bq} / \mathrm{m}^{3}$ in the factories, the limits of ICRP are not exceeded in any of the buildings in the region. In addition, the estimated mean annual effective doses to the people in the workplace, students, office workers and factory workers have been calculated as $0.27,0.63$ and $0.20 \mathrm{mSv} / \mathrm{y}$, respectively for the region.

\section{Introduction}

Radon is the heaviest gas in the natural decay series of uranium, thorium and actinium. ${ }^{222} \mathrm{Rn}$ (usually called radon), since it can decay to solid $\left({ }^{218} \mathrm{Po},{ }^{214} \mathrm{~Pb},{ }^{214} \mathrm{Bi},{ }^{214} \mathrm{Po}\right)$ in the lung is the most important isotope for human health. It has a halflife of 3.825 days and is ubiquitous in the environment. ${ }^{222} \mathrm{Rn}$ emanates from soil and rock, which is also the main source of radon in the atmosphere. The concentration of atmospheric ${ }^{222} \mathrm{Rn}$, therefore, depends on the rate of diffusion from the ground and advection/diffusion in the air (Rahman et al. 2009). The primary natural sources of indoor radon are soil, building materials (sand, rocks, cement, etc.), radon dissolved in and transported by water, natural energy sources such as gas, coal, etc., which contain traces of ${ }^{238} \mathrm{U}$ (Banman et al. 1982). The design of the building is the important factor affecting the concentration of indoor radon. This is why the ventilation system, the heating and cooling system, the sanitary fittings, etc., all play an important role in the contribution of radon inside the buildings (Rahman et al. 2009). Concentrations of radon in a building vary with time both diurnally and seasonally. These variations are primarily due to the effect of meteorological changes on radon levels in soil gas and also to weather-related changes to building ventilation (IAEA 2003). Relatively higher indoor radon levels have been observed during the winter season (Durrani and Ilic 1997).

Although radon is chemically inert and electrically uncharged, when the resulting atoms, called

Keywords. CR-39; effective dose; health hazard; indoor air; radon; workplaces. 
radon progeny, are formed, they are electrically charged and can attach themselves to tiny dust particles in indoor air. Alpha particles from the decay of radon progeny that are deposited in the lungs cannot reach any other organs, so it is likely that lung cancer is the only potential important cancer hazard posed by radon in indoor air (BEIRVI 1999).

Recently, radon investigations have been concentrated specifically in workplaces all over the world. However, there have not been any significant radon studies for the workplaces in Turkey. The goals of this study are to determine the radon concentrations and effective radiation doses exposed by radon in workplace buildings at the city centre of Adapazarı, and to find the relationship of the radon concentrations between different types of workplaces.

\section{Survey area}

For this research, the city of Adapazarı was chosen for several reasons. First of all Adapazarı is one of the most important economical centre in Turkey along with its high population $(242,000)$. Adapazarı is located at the northwestern part of the country (map is shown in figure 1) and it carries the common climatic and geographical characteristics within the big cities. The precipitation in this region is high and is humid for all seasons. The soil structure generally consists of clay and sand in large part of the region. The region lies along the North Anatolian Fault.

\subsection{Characteristics and properties of the buildings}

This research has been performed for three types of workplaces: schools, offices and factories. Before the research was started, a survey form was prepared for the participants containing questions about the type of structural material, age of the building, work hours, holidays, etc. All of the state school buildings, including primary, elementary and high schools were covered under this investigation.

The building material of the schools is concrete so the thermal insulation is not perfect. Because of high humidity, all buildings are regularly aerated. The schools in this region of Turkey are active for eight months out of the year and the school buildings are used only on weekdays for educational purposes.

The offices investigated for this research have been selected randomly, each carrying one to ten workers per office. On average, these workers work 9 hours per day and 6 days per week. The office buildings are reinforced with concrete. Note that the offices have better thermal insulation compared to the schools and are also regularly aerated due to high humidity.

The industrial factories are located in the same research area ( $2 \mathrm{~km}$ away from the city centre), and the soil characteristic of this area is the same with other workplaces investigated. The main industrial factories in Adapazarı are: automobile, metal, heavy machine, textile, electronic, furniture and food. The selected factories have 20-500 workers

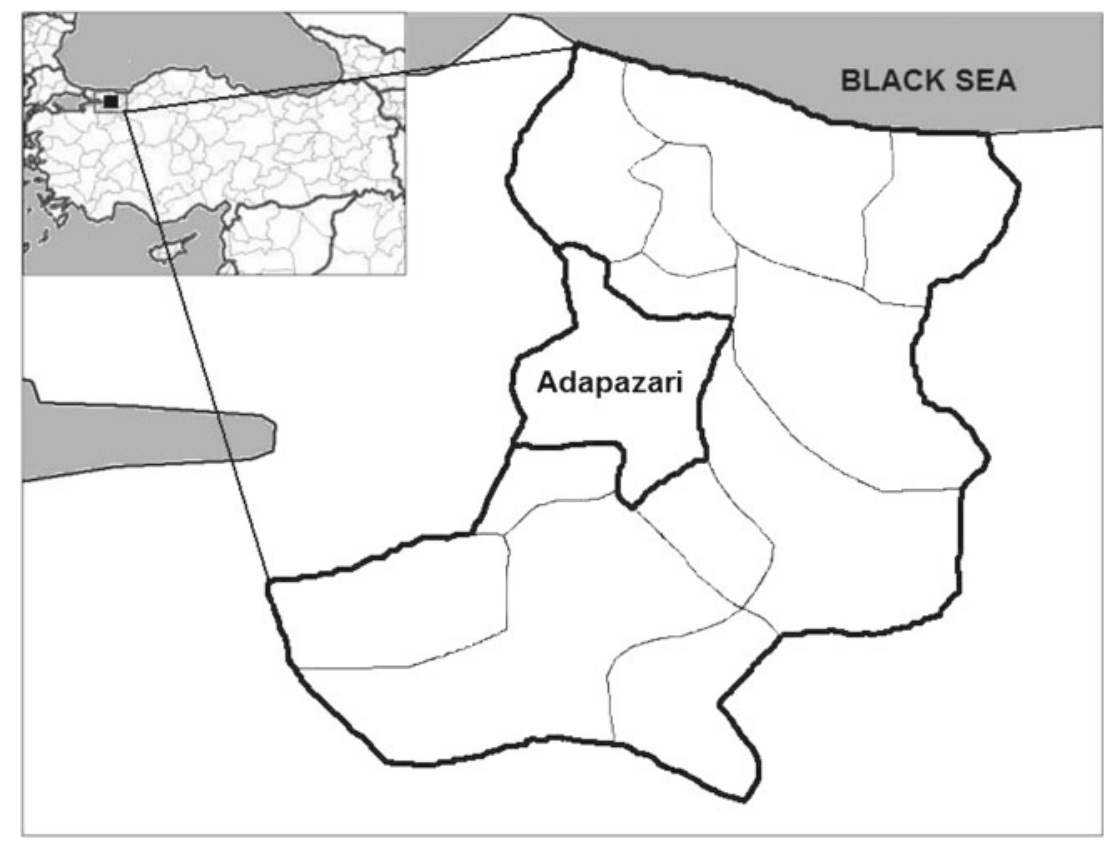

Figure 1. Survey region, the city of Adapazarı. 
Table 1. The radon concentrations measured in the region.

\begin{tabular}{lccccc}
\hline Place & $\begin{array}{c}\text { Number of } \\
\text { measurements }\end{array}$ & $\begin{array}{c}\text { Min. RAC } \\
\left(\mathrm{Bq} / \mathrm{m}^{3}\right)\end{array}$ & $\begin{array}{c}\text { Max. RAC } \\
\left(\mathrm{Bq} / \mathrm{m}^{3}\right)\end{array}$ & $\begin{array}{c}\text { Mean RAC } \\
\left(\mathrm{Bq} / \mathrm{m}^{3}\right)\end{array}$ & $\begin{array}{c}\text { St. deviation } \\
\left(\mathrm{Bq} / \mathrm{m}^{3}\right)\end{array}$ \\
\hline School & 45 & 33 & 151 & 66 & 32 \\
Office & 37 & 45 & 173 & 76 & 26 \\
Factory & 36 & 15 & 52 & 27 & 24 \\
Outdoor & 9 & 5 & 18 & 14 & 4 \\
\hline
\end{tabular}

employed on location. The workers work 8 hours per day and 6 days per week. The factories are made of prefabricated materials with steel construction and have large volumes, usually with one single large storey. These buildings do not have enough thermal insulation and they were mostly well ventilated depending on the amount of chemicals used.

\section{Materials and methods}

For this survey, passive radon detectors of CR-39, and solid state nuclear track detector (SSNTD) were used. The survey was carried out from winter to spring. The detectors were installed in 45 schools, 37 offices, 36 factories and 9 outdoor locations. The detectors were setup in one classroom in each school, one working room in each office and one for each of the factories. All detectors were placed on the first floor (ground floor) and about $1 \mathrm{~m}$ above the ground. In order to understand the radon concentration differences between the buildings, the ventilation systems, the frequency of the aeration, thermal insulation, the working hours, and the building construction features have been carefully considered during our evaluations. The detectors were also placed in many outdoor fields in order to obtain regional radon distribution in the research area. After 75 days of radon exposure, the CR-39 detectors were etched in $25 \% \mathrm{NaOH}$ at $80^{\circ} \mathrm{C}$ locally during 6 hours and the number of tracks in each film was counted by the automatic reader microscope, at the Department of Radioactivity Analysis in the Çekmece Nuclear Research and Training Center (CNRTC) in Istanbul. A calibration factor of 2.58 tracks $\mathrm{cm}^{-2} \mathrm{~h}^{-1} \mathrm{kBq}^{-1} \mathrm{~m}^{-3}$ was used to calculate the radon concentration (Radosys 2000).

In order to estimate the annual indoor mean effective dose $E(\mathrm{mSv} / \mathrm{y})$ of radon and its progeny, the UNSCEAR-2000 recommended conversion factors were applied to our calculations (UNSCEAR 2000; Maged 2006). According to the UNSCEAR model, the annual effective dose, $E$, is

$$
E(\mathrm{mSv} / \mathrm{y})=C \times F \times H \times T \times D,
$$

Table 2. Average radon concentrations for different industry types.

\begin{tabular}{lccc}
\hline $\begin{array}{l}\text { Industry } \\
\text { type }\end{array}$ & $\begin{array}{c}\text { Number of } \\
\text { structure }\end{array}$ & $\begin{array}{c}\text { Average RAC } \\
\left(\mathrm{Bq} / \mathrm{m}^{3}\right)\end{array}$ & $\begin{array}{r}\text { St. deviation } \\
\left(\mathrm{Bq} / \mathrm{m}^{3}\right)\end{array}$ \\
\hline Automotive & 8 & 32 & 14 \\
Electronic & 6 & 39 & 4 \\
Metal & 6 & 26 & 12 \\
Textile & 4 & 8 & 3 \\
Various & 12 & 26 & 13 \\
Total & 36 & 27 & 13 \\
\hline
\end{tabular}

where $C$ is the ${ }^{222} \mathrm{Rn}$ concentration (in $\mathrm{Bq} / \mathrm{m}^{3}$ ), $F$ is the equilibrium factor between radon and its decay products which is assumed to be 0.4 for the buildings (UNSCEAR 2000), $H$ is the occupancy factor, $T$ is the number of hours in a year $(8760 \mathrm{~h} / \mathrm{y})$ and $D$ is the dose conversion factor $\left(9.0 \mathrm{nSv} / \mathrm{Bq} / \mathrm{m}^{3} / \mathrm{h}\right)$. In the present case, the value of $H$ was calculated for each type of labour by considering the working hours for workplaces in Turkey. The equilibrium equivalent concentration (EEC) of the atmosphere can be obtained by multiplying the concentration of the gas $(C)$ and the equilibrium factor $(F)$.

\section{Results and discussion}

\subsection{Radon concentrations in buildings}

Table 1 shows the calculated mean, minimum and maximum radon concentrations within standard deviations in the schools, offices, factories and outdoor fields in Adapazarı. The outdoor radon concentrations were very close to each other. In addition, the average radon concentrations in factories have been found to be much lower than the school and the office buildings. The superior ventilation systems, very large open spaces, and doors and windows kept open for longer time in the factories are the main reason for this lower radon concentration. Table 2 shows the mean radon concentrations of different types of industrial facilities. The average radon concentrations for textile and 
metal industries have been determined to be the lowest in this industrial zone because these factories use very large ventilation systems to evacuate the chemicals from painting.

This research has been performed during the educational period. The average radon concentrations in school buildings have been determined to be less than the radon concentrations in office buildings. The better heat insulation in the office buildings is one of the main reasons that the radon gas concentration is higher compared to school buildings.

In ICRP report no. 65, the maximum action level for the radon exposure was recommended as 3$10 \mathrm{mSv} / \mathrm{y}$ (ICRP 1993). The radon concentrations corresponding to these dose levels are between 200 and $600 \mathrm{~Bq} / \mathrm{m}^{3}$ for both home and offices, and 500 to $1500 \mathrm{~Bq} / \mathrm{m}^{3}$ for workplaces. As seen in table 1 , the maximum radon concentrations were found to be $151 \mathrm{~Bq} / \mathrm{m}^{3}$ in schools, $173 \mathrm{~Bq} / \mathrm{m}^{3}$ in offices, and $52 \mathrm{~Bq} / \mathrm{m}^{3}$ in factories, and these values are lower than the recommended ICRP dose limits.

Table 3 compares the recent radon gas exposure studies from other countries with this research for schools, offices and factories. As seen in table 3, the mean radon concentrations in other countries differ from this research based on the soil characteristics. Table 3 also shows that the radon concentration in Japan and in Adapazarı have some correlations.

\subsection{Dose estimation}

The annual effective radiation dose due to radon gas accumulation indoors have been calculated using equation (1) with the following considerations: (a) the occupancy factors given in table 4, (b) the average radon concentrations for each type of workplace given in table 1 , and (c) the related factors

Table 3. Radon concentration studies for the workplaces in different countries.

\begin{tabular}{|c|c|c|c|c|c|}
\hline $\begin{array}{l}\text { Type of } \\
\text { workplace }\end{array}$ & Country & Year & $\begin{array}{l}\text { Average RAC } \\
\quad\left(\mathrm{Bq} / \mathrm{m}^{3}\right)\end{array}$ & $\begin{array}{l}\text { Number of } \\
\text { buildings }\end{array}$ & Reference \\
\hline \multirow[t]{8}{*}{ School } & Kuwait & 2006 & 16 & 25 & UNSCEAR (2000) \\
\hline & Japan & 2006 & 28 & 185 & Oikawa et al. (2006) \\
\hline & Ireland & 2004 & 93 & 3444 & Colgan et al. (2004) \\
\hline & Belgium & 1992 & 120 & 421 & Poffijn et al. (1992) \\
\hline & Italy & 2008 & 144 & 30 & Venoso et al. (2009) \\
\hline & Greece & 2009 & 231 & 77 & Clouvas et al. (2009) \\
\hline & Iran & 1990 & 256 & 16 & Sohrabi et al. (1990) \\
\hline & Turkey & 2009 & 66 & 45 & Present study \\
\hline \multirow[t]{4}{*}{ Office } & Japan & 2006 & 23 & 287 & Oikawa et al. (2006) \\
\hline & Hong Kong & 2007 & 37 & 216 & Mui et al. (2008) \\
\hline & Pakistan & 2009 & 64 & 105 & Rahman et al. (2009) \\
\hline & Turkey & 2009 & 76 & 37 & Present study \\
\hline \multirow[t]{2}{*}{ Factory } & Japan & 2006 & 10 & 178 & Oikawa et al. (2006) \\
\hline & Turkey & 2009 & 27 & 36 & Present study \\
\hline
\end{tabular}

Table 4. Annual occupation and occupancy factors (H) for different types of labour.

\begin{tabular}{llccccc}
\hline $\begin{array}{l}\text { Type of } \\
\text { workplace }\end{array}$ & Labour & $\begin{array}{c}\text { Working hour } \\
\text { per day }\end{array}$ & $\begin{array}{c}\text { Working day } \\
\text { per week }\end{array}$ & $\begin{array}{c}\text { Working week } \\
\text { per year }\end{array}$ & $\begin{array}{c}\text { Annual } \\
\text { occupation (h) }\end{array}$ & $\begin{array}{c}\text { Occupancy } \\
\text { factor }\end{array}$ \\
\hline School & Teacher-staff & 8 & 5 & 40 & 1600 & 0.18 \\
School & Pupil & 6 & 5 & 32 & 960 & 0.11 \\
Factory & Worker & 7 & 6 & 48 & 2016 & 0.23 \\
Office & Officer & 8 & 6 & 48 & 2304 & 0.26 \\
\hline
\end{tabular}

Table 5. Annual effective doses for different types of labour.

\begin{tabular}{llcccc}
\hline $\begin{array}{l}\text { Type of } \\
\text { workplace }\end{array}$ & Labour & $H$ & $\begin{array}{c}\mathrm{RAC} \\
\left(\mathrm{Bq} / \mathrm{m}^{3}\right)\end{array}$ & $\begin{array}{c}\mathrm{EEC} \\
\left(\mathrm{Bq} / \mathrm{m}^{3}\right)\end{array}$ & $\begin{array}{c}\text { AED } \\
(\mathrm{mSv} / \mathrm{y})\end{array}$ \\
\hline School & Teacher-staff & 0.18 & 66 & 26 & 0.38 \\
School & Pupil & 0.11 & 66 & 26 & 0.27 \\
Factory & Worker & 0.23 & 27 & 11 & 0.20 \\
Office & Officer & 0.26 & 76 & 30 & 0.63 \\
\hline
\end{tabular}


explained in the materials and methods section. Table 5 shows the annual effective doses for school staff, employees in the offices and factory workers in the Adapazarı area. The annual highest and lowest doses to humans have been determined as 0.63 and $0.20 \mathrm{mSv}$ for offices and factories, respectively, depending on the occupancy and radon gas accumulation.

\section{Conclusion}

In conclusion, a survey consisting of 127 radon measurements has been performed in schools, offices, and in factories at Adapazarı. The results showed that:

- The average radon concentrations decrease in the following order: offices, schools and factories.

- The differences in radon concentration mostly originate from the frequency of indoor air changes, ventilation and insulation factors of these buildings.

- The average radon concentrations in different types of industrial facilities decreased as follows: automotive, electronic, metal and textile factories.

- The cause of the differences is mostly from the ventilation system and the usage of chemicals. Clearly, a better ventilation system has a big impact on decreasing the radon exposures in these industrial buildings.

- All the estimated effective doses delivered to the workers/students due to the indoor radon were found to be less than the lower limit of ICRP recommended action levels of $3-10 \mathrm{mSv} / \mathrm{y}$.

\section{Acknowledgements}

The authors are thankful to Drs Birsen AyazMaierhafer and Dan Maierhafer for their unique support and cooperation in the preparation of this paper.

\section{References}

Banman A, Hervat D J and Lokobauer N 1982 In: Natural radiation environment (ed.) Vahra K J, Wiley Eastern, New Delhi, pp. 401-415.

BEIR-VI Committee on health risks of exposure to radon National Research Council 1999 Health effects of exposure to radon; National Academy Press, Washington DC.

Clouvas A, Takoudis G, Xanthos S, Potiriadis C and Kolovou M 2009 Indoor radon measurements in areas of northern Greece with relatively high indoor radon concentrations; Radiat. Prot. Dosim. 136(2) 127-131.

Colgan P A, Madden J S, Synnott H, Fennell S, Pollard D and Fenton D 2004 Current status of programmes to measure and reduce radon exposure in Irish workplaces; J. Radiol. Prot. 24 121-129.

Durrani S A and Ilic R 1997 Radon measurements by etched track detectors; World Scientific Publishing Co., Singapore.

IAEA International Atomic Energy Agency 2003 Radiation protection against radon in workplaces other than mines, Safety Reports Series No. 33.

ICRP International Commission on Radiological Protection 1993 Protection against ${ }^{222} \mathrm{Rn}$ at home and at work; Annals of ICRP, Pergamon Press, Oxford, Rept No. 65.

Maged A F 2006 Radon concentrations in elementary schools in Kuwait; Health Phys. 90(3) 258-262.

Mui K W, Wong L T and Hui P S 2008 An approach to assessing the probability of unsatisfactory radon in airconditioned offices of Hong Kong; J. Environ. Radioac. 99(2) 248-259.

Oikawa S, Kanno N, Sanada T, Abukawa J and Higuchi H 2006 A survey of indoor workplace radon concentration in Japan; J. Environ. Radioac. 87 239-245.

Poffijn A, Uyttenhove J, Drouget B and Tondeur F 1992 The radon problem in schools and public buildings in Belgium; Radiat. Prot. Dosim. 45(1/4) 499-501.

Radosys 2000 User's Manual.

Rahman S U, Rafique M and Matiullah Anwar J 2009 Radon measurement studies in workplace buildings of the Rawalpindi region and Islamabad capital area, Pakistan; Build. Environ. 45(2) 421-426.

Sohrabi M, Zainali H, Mahdi S, Solamanian A R and Salehi M 1990 Determination of ${ }^{222} \mathrm{Rn}$ levels in houses, schools and hotels of Ramsar by AEOI passive radon diffusion dosimeters; High Levels of Natural Radiation, Proc. Int. Conf. Ramsar, Islamic Republic of Iran.

UNSCEAR United Nations Scientific Committee on the Effects of Atomic Radiation 2000 Sources, effects and risks of ionizing radiation, Report to General Assembly with Scientific Annexes United Nations, United Nations, New York.

Venoso G, De Cicco F, Flores B, Gialanella L, Pugliese M, Roca V and Sabbarese C 2009 Radon concentrations in schools of the Neapolitan area; Radiat. Meas. 44 127-130. 